\title{
Trends of significant wave height and sea level in the southern water of the Special Region of Yogyakarta
}

\author{
Martono*, Indah Susanti, Bambang Siswanto, Amalia Nurlatifah, Mamat Suhermat, and Edy Maryadi \\ Center of atmospheric science and technology, National Institute of Aeronautics and Space, Indonesia
}

\begin{abstract}
Coastal zone is very vulnerable to the impacts of climate change. The increase of sea wave and sea level rise threaten coastal zone. The purpose of this study is to determine trends of significant wave height and sea level in the southern waters of the special region of Yogyakarta. The data used consists of daily significant wave height from 2010-2018, weekly absolute dynamics topography from 2005-2018 and daily surface wind from 2010-2018. Trends of significant wave height and sea level were analyzed by using linear regression. The results showed that significant wave height during the east season until the second transition season was higher than the west season and the first transition season. Vice versa, sea level during the east season until the second transition season was lower than the west season and the first transition season. Trends of significant wave height has increased of $0.63 \mathrm{~cm} /$ year, meanwhile sea level rise reached $0.82 \mathrm{~cm} /$ years.
\end{abstract}

Keywords: trends, significant wave height, sea level, climate change, coastal zone

\section{Introduction}

Province of the special region of Yogyakarta has established that the coastal zone as the center of new economic growth. To support this program has carried out the construction and development of several infrastructure of coastal zone. Some of the infrastructure under construction is the New Yogyakarta International Airpot and Gesing port, meanwhile the development of infrastructure in the Tanjung Adikarto port and Sadeng port.

Coastal zone is very vulnerable to the impacts of climate change. Some impacts of climate change that threaten coastal zone among other sea level rise and intensity increase of storm [1]. Climate change has caused change the characteristics of ocean wave [2]. Some of these change among other extreme wave which caused by an increased frequency of tropical cyclones and ocean wave to be stronger [3, 4].

The projection results shows that sea wave height in the Indonesian waters will increase between 0.5-1 m [5]. Based on ERA-Interim data from 1980-2014, the velocity and wave height in the southern waters of Java has increased [6]. In the Indonesian waters, wave height of more than $2 \mathrm{~m}$ are only found in the southern waters of Java [7], so that these waters has the potential for the development of wave energy [8].

The increase frequency of extreme weather which causes extreme wave has a major impact on various human activities and infrastructure in the coastal zone
$[9,10]$. The purpose of this study was to determine the trends of significant wave height and sea level in the southern waters of Yogyakarta. The results of this study are expected to support sustainable development management in the coastal zone of the special region of Yogyakarta.

\section{Research Methods}

The research location is the southern waters of the special segion of Yogyakarta from the coastline to $8^{\circ} \mathrm{S}$ and $110^{\circ}$ $\mathrm{E}-111^{\mathrm{O}} \mathrm{E}$ as shown in Figure 1. The data used consists of daily significant wave height from 2010-2018, weekly absolute dynamic topography from 2005-2018 and daily surface wind from 2010-2018. Surface wind data covers the coastline to $10^{\mathrm{O}} \mathrm{S}$ and $109^{\circ} \mathrm{E}-112^{\mathrm{O}} \mathrm{E}$. Surface wind data consists of zonal and meridional components. The topography data was used for identify the typology of Yogyakarta's coast. Significant wave height and absolute dynamic topography data were obtained from AVISO with the website: https://las.aviso.altimetry.fr/. AVISO data retrieved from the satellite and buoys that were mathced in space and time. While surface wind data was obtained from CERSAT with the website: http://cersat.ifremer.fr/. CERSAT data is gridded daily wind vector and wind stress fields, estimated over global ocean from QuikSCAT scatterometer (referred as DQSCAT) data.

These data were analyzed by using statistics methods. Surface wind velocity was determined based on

\footnotetext{
* Corresponding author: martono@lapan.go.id
} 
zonal and meridional components with the following equation:

$$
R=\sqrt{U^{2}+V^{2}}
$$

Where $\mathrm{R}$ is the surface wind velocity, $\mathrm{U}$ is the zonal component of surface wind and $\mathrm{V}$ is the meridional component of surface wind. Daily and weekly data were converted to monthly data. Then, monthly data was processed into seasonal average. For the purpose of analysis this study, the season was divided into four namely the west season from December-February, the first transitional season from March-May, the east season from June-August and the second transitional season from September-November. Analysis of linear regression was used to determine trends of significant wave height, sea level and surface wind velocity.

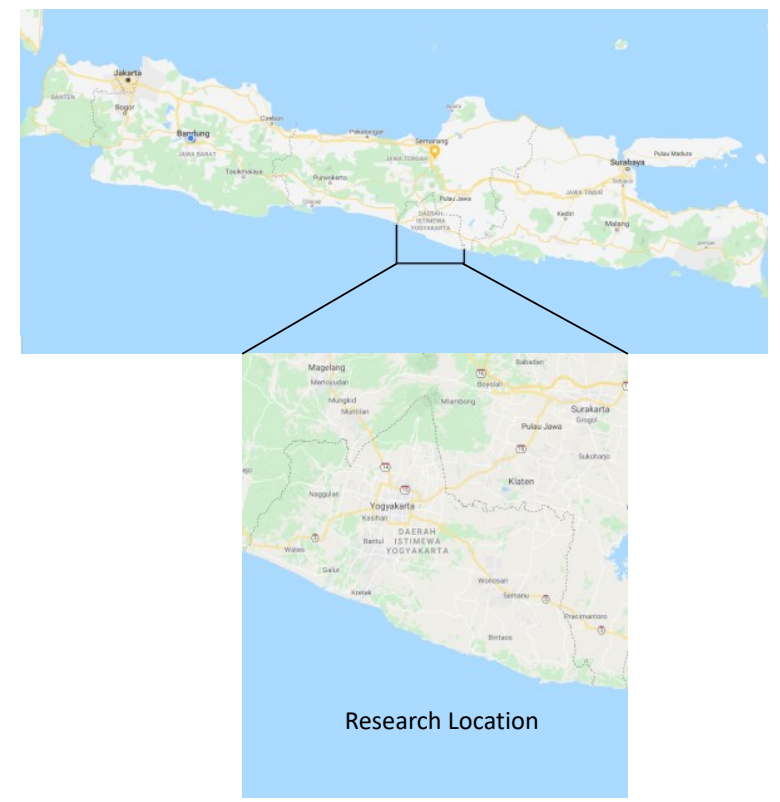

Fig.1. Research location

\section{Results and Discussions}

Figure 2 shows the seasonal pattern of significant wave height in the southern waters of the special region of Yogyakarta. The significant wave height is different for each season. The highest significant wave height occurred in the east season which reached $1.75 \mathrm{~m}$, while the lowest significant wave height occurred in the first transition season around $1.42 \mathrm{~m}$. The significant wave height in the west season and the second transition season of about 1.48 $\mathrm{m}$ and $1.50 \mathrm{~m}$

Time series of seasonal significant wave height in the southern waters of the special region of Yogyakarta as shown Figure 3. Seasonal variation of significant wave height fluctuated with the lowest value of $1.34 \mathrm{~m}$ and the highest value up to $1.96 \mathrm{~m}$. The significant wave height in these waters was smaller than average in the southern of
Java with a range of $1.4 \mathrm{~m}$ to $2.4 \mathrm{~m}$ [11]. From 2010-2018, trends of the significant wave height has increased by about of $0.56 \mathrm{~cm} /$ year. This value was lower than the results of other researchers, that an increased of the significant wave height in the southern waters of the special region of Yogyakarta up to $0.75 \mathrm{~cm} /$ year in the period 1984-2003 [12].
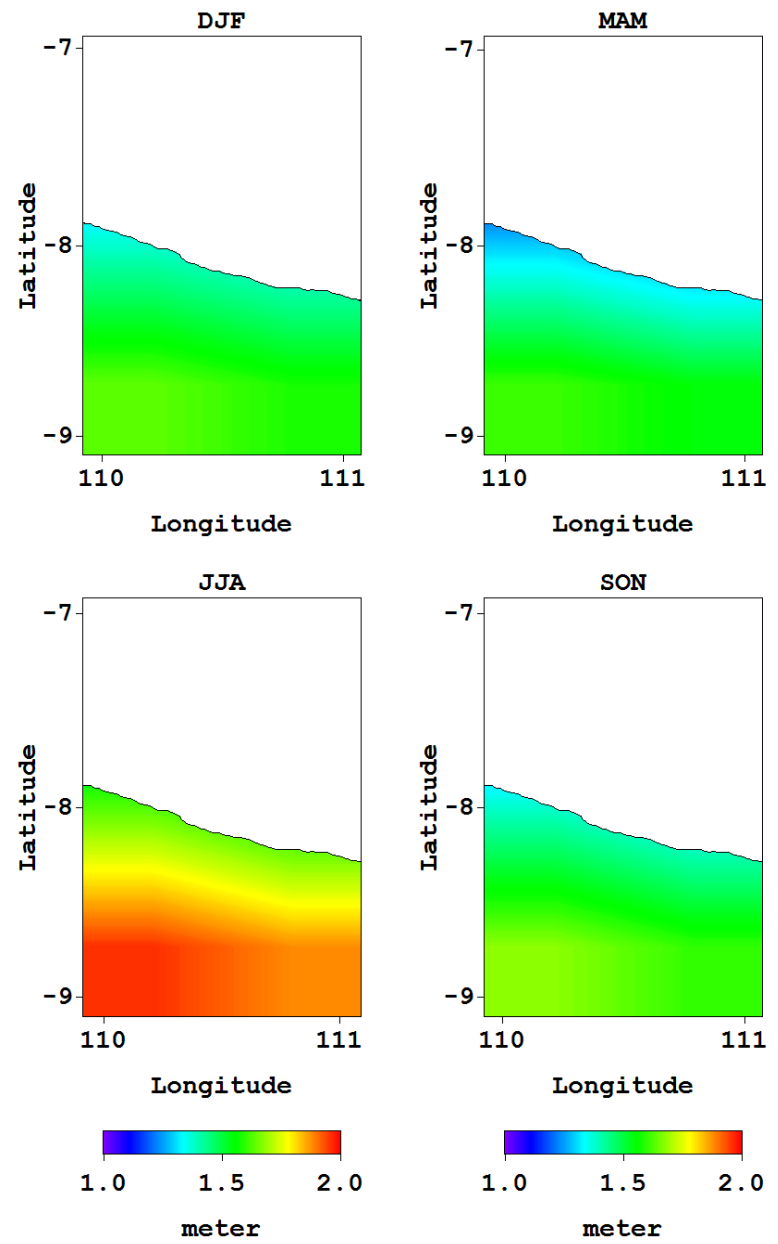

Fig. 2. Seasonal pattern of significant wave height

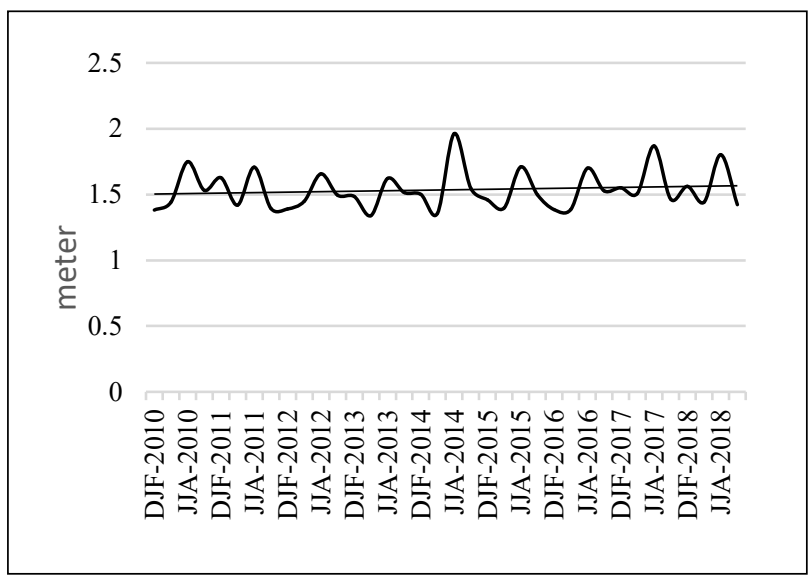

Fig. 3. Time series of significant wave height

Figure 4 shows the seasonal pattern of sea level in the southern waters of the special region of Yogyakarta. The seasonal pattern of sea level was different from the 
significant wave height. Generally, the seasonal pattern of sea level was inversely proportional to significant wave height. The highest sea level occured in the west season around $96.3 \mathrm{~cm}$, then dropped until the second transition season reached $78.9 \mathrm{~cm}$. Sea level in the first transition season and the east season around $92.5 \mathrm{~cm}$ and $80.9 \mathrm{~cm}$. The difference of sea level between the west season and the second transition season reached $17.4 \mathrm{~cm}$.
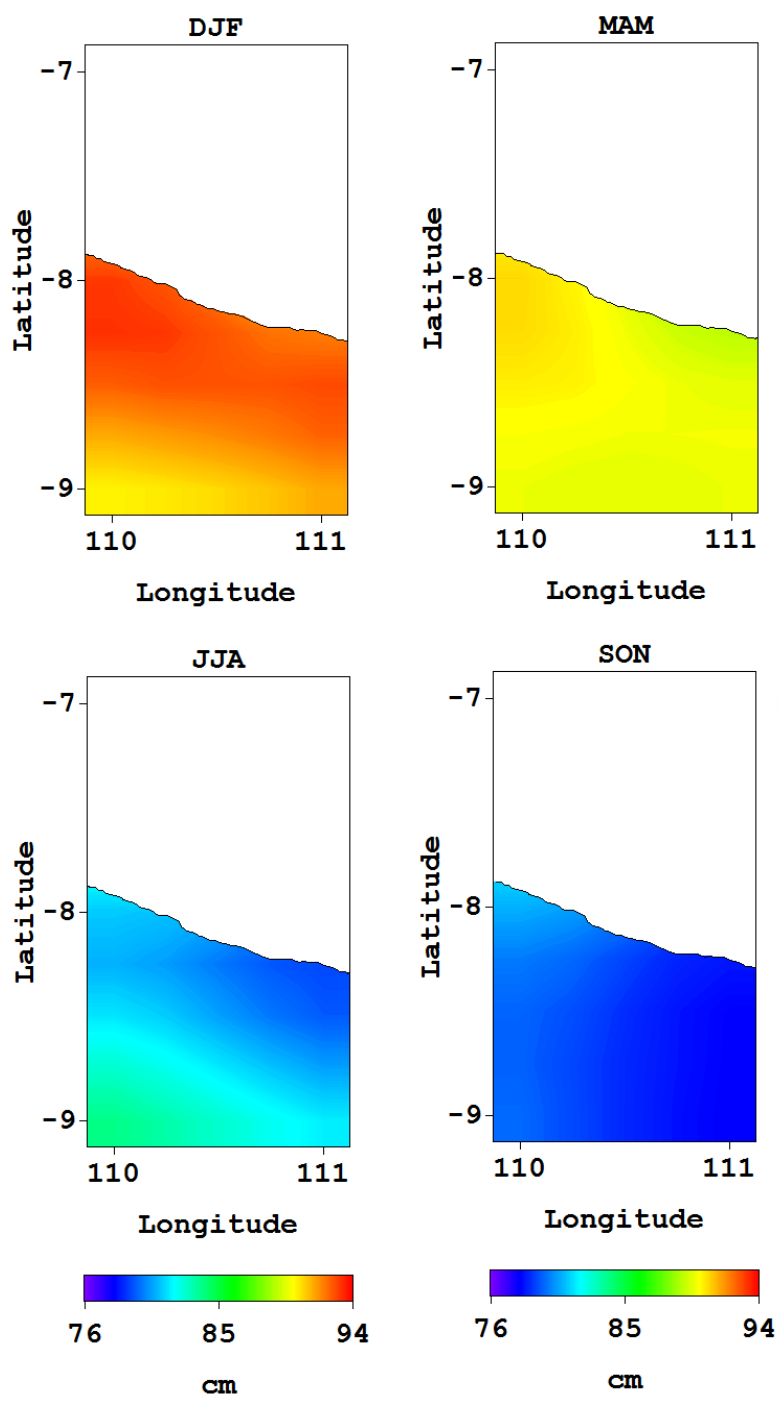

Fig. 4. Seasonal pattern of sea level

Time series of seasonal sea level in the southern waters of the special region of Yogyakarta as shown Figure 5. Based on Figure 4 that seasonal variation of sea level very fluctuated. Fluctuation of sea level was quite high with the lowest value of $60.1 \mathrm{~cm}$ and the highest value up to $107.3 \mathrm{~cm}$, so the difference of seasonal sea level reached $47.2 \mathrm{~cm}$. Trends of sea level rise has reached $0.82 \mathrm{~cm} /$ years.

Based on the results it is known that significant wave height and sea level in the southern waters of special region of Yogyakarta different for each season and tends to an increased. This seasonal change is influenced by atmospheric dynamics, especially surface wind circulation in the southern waters of Java. Figure 6 shows the seasonal pattern of surface wind circulation in the southern waters of Central Java. During the west seasonal surface wind moves to the east, whereas in the first transitional season until the second transitional season surface wind moves to the west.

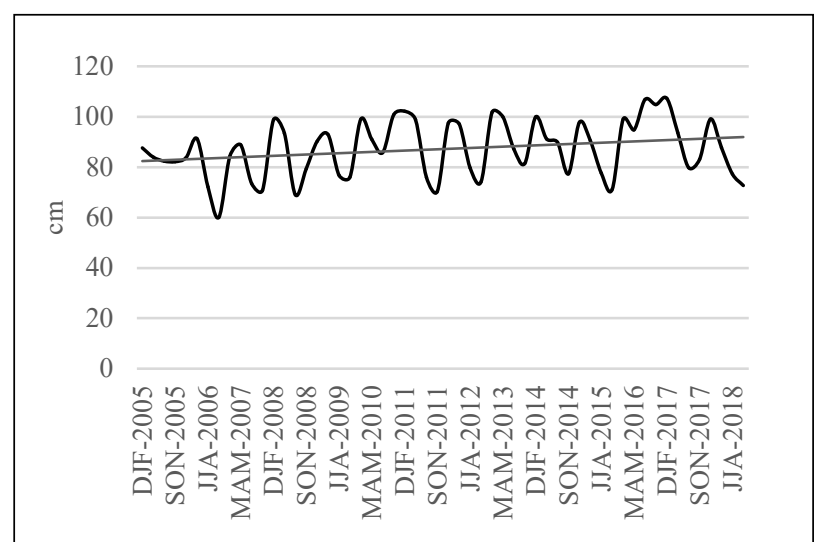

Figure 5. Time series of sea level

Surface wind is the main driving of sea wave. The highest surface wind velocity occured in the east season which reached $7.04 \mathrm{~m} / \mathrm{sec}$ and the lowest in the first transitional season around $2.67 \mathrm{~m} / \mathrm{sec}$. Surface wind velocity in the west season and the second transition season of about $3.27 \mathrm{~m} / \mathrm{sec}$ and $5.36 \mathrm{~m} / \mathrm{sec}$. Therefore, seasonal variation of significant wave height has the same pattern as surface wind velocity. The correlation coefficient between significant wave height and surface wind velocity reached 0.91 . This condition which causes significant wave height in the east season and the second transition season is higher than in the west season and the first transition season.
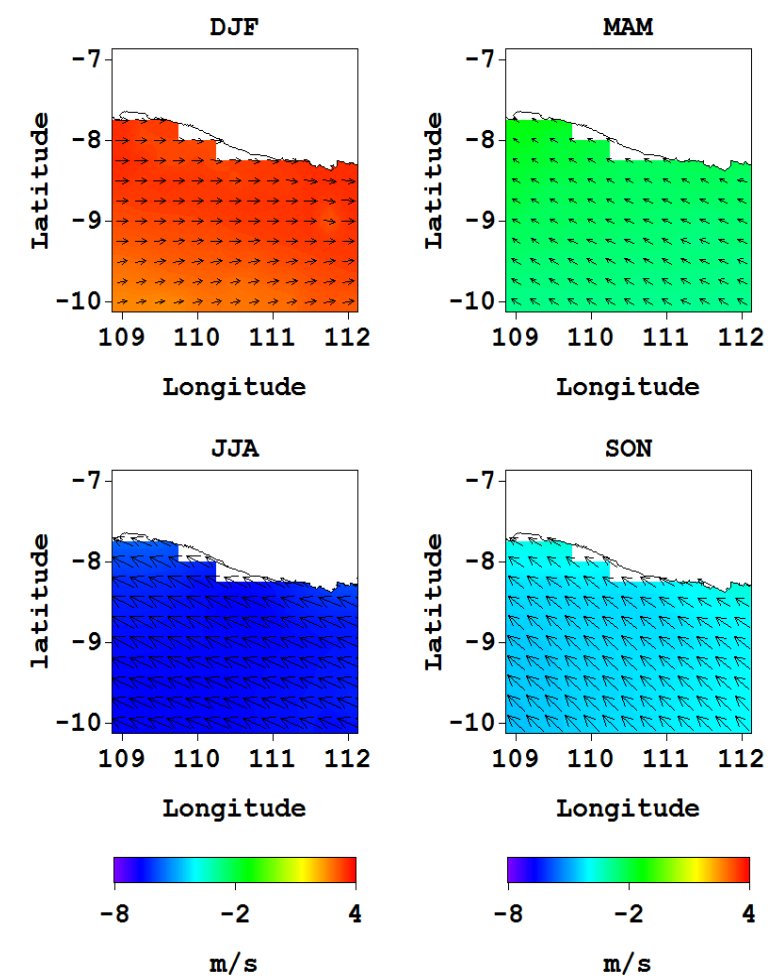

Fig. 6. Monthly pattern of wind circulation 
Fluctuation of significant wave height is influenced by surface wind strength. Therefore, when the surface wind velocity is stronger, so significant wave height is higher. Time series of seasonal surface wind velocity in the southern waters of Central Java as shown Figure 7. From 2010-2018, the trends of surface wind velocity in these waters has increased around $2.71 \mathrm{~cm} /$ year. This an increase of surface wind velocity which caused trends of significant wave height in the southern waters of the special region of Yogyakarta has increased from year to year.

Seasonal variation of sea level in the southern waters of special region of Yogyakarta is quite high. Sea level in the east season to the second transition season is lower than in the west season until the first transition season. The decrease of sea level during the east season until the second transition is caused by the upwelling process. Upwelling is the process of rising the mass of water from below to the surface layer. The upwelling process is generated by the southeast monsoon which moves to the west $[13,14]$. The process of upwelling in the southern waters of Java occurs between June to October. Upwelling causes the surface water masses in the coastal zone moves to the offshore waters, so that sea level in the coastal zone decreases. This mechanism which causes sea level in the east season to the second transition season to decrease.

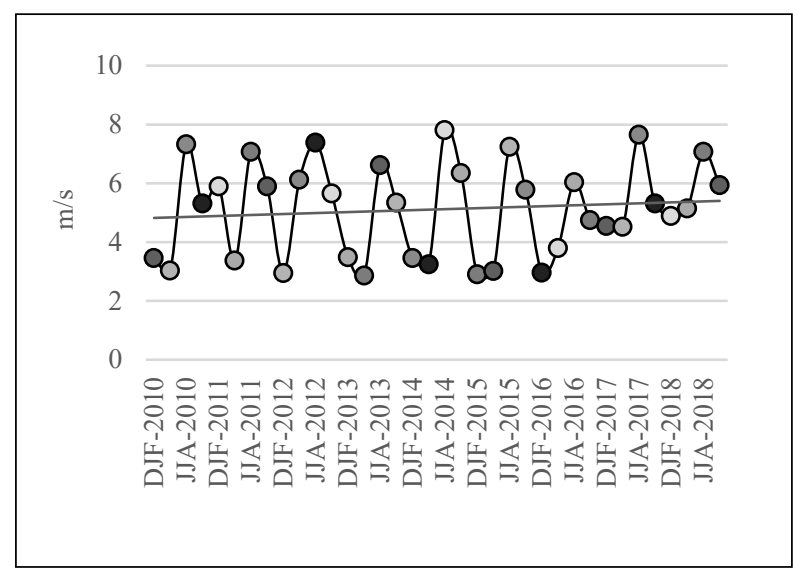

Fig. 7. Time series of surface wind velocity

\section{Conclusion}

Based on the results it can be concluded that seasonal variation of significant wave height and sea level in the southern waters of the special region of Yogyakarta was influenced by surface wind circulation. Seasonal variation of significant wave height and sea level were different for each season. Seasonal pattern of significant wave height was inversely proportional to sea level. Trends of significant wave height and sea level in these waters showed an increase. From 2010-2018 significant wave height increased around $0.63 \mathrm{~cm} /$ year and sea level rise reached $0.82 \mathrm{~cm} /$ years from 2005-2018. Meanwhile, surface wind velocity has increased of about of 2.71 $\mathrm{cm} /$ year from 2010-2018
The author would like to thank PSTA-LAPAN for providing funding for this research.

\section{References}

1. S. Dasgupta, B. Laplante, C. Meisner, D. Wheeler, J. Yan, World Bank Policy Research Working Paper 4136

2. I. Sofian, A. Supangat, M. S. Fitrianto, R. Kurniawan, Jurnal Meteorologi dan Geofisika 12, 1(2011)

3. N. Mori, T. Yasuda, H. Mase, T. Tom, Y. Oku, Hydrological Research Letters 4, (2010)

4. B. G. Reguero, I. J. Losada, F. J. Mendez, Nat. Commun 10, 205(2019)

5. RAN-API, Policy Brief Marine Sector 2018

6. M. Zikra, P. Ashfar, J. Ocean, Mechanical and Aerospace - science and engineering- 24, (2015)

7. R. Kurniawan, M.K. Khotimah, IPTEK, The Journal for Technology and Science 26, 1(2015)

8. M. Zikra, P. Ashfar, Mukhtasor, ARPN Journal of Engineering and Applied Sciences 11, 2(2016)

9. D. D. Luccio, G. Benassai, G. Budillon, L. Mucerino, R. Montella, E.P. Carratelli, Nat. Hazards Earth Syst. Sci 18, (2018)

10. K. Taniguchi, J. Mar. Sci. Eng 7, 150(2019)

11. N. P. Purba, J. K, R. Sandro, S. Gibran, R. A. I. Permata, F. Maulida, M.K. Martasuganda, Energy Procedia, 65(2015)

12. M. Zikra, Suntoyo, Lukijanto, Procedia Earth and Planetary Science, 14(2015)

13. R.D. Susanto, A. L. Gordon, Q. Zheng, Geophysical Research Letter 28, 8(2001)

14. T. Qu, Y. Du, J. Strachan, G. Meyers, J. Slingo, Oceanography $18,4(2005)$ 